УДК 616.981.455:576.858.9

\title{
А.А.Григорьев ${ }^{1}$, И.В.Борисевич ${ }^{1}$, И.В.Дармов ${ }^{1}$, В.П.Бондарев ${ }^{1}$, С.Л.Кузнецов ${ }^{1}$, А.В.Миронин ${ }^{1}$, И.П.Погорельский ${ }^{1}$, А.В.Летаров ${ }^{2}$, Е.Е.Куликов ${ }^{2}$, А.А.Маныкин ${ }^{3}$
}

\section{ВЫДЕЛЕНИЕ И СВОЙСТВА ТУЛЯРЕМИЙНОГО БАКТЕРИОФАГА ГАЛ}

\author{
${ }^{1}$ ФГУ «48 Центральный научно-исследовательский институт МО РФ», Киров; \\ ${ }^{2}$ Институт микробиологии им. С.Н.Виноградского РАН, ${ }^{3}$ Научно-исследовательский институт \\ вирусологии им. Д.И.Ивановского РАМН, Москва
}

\begin{abstract}
Впервые выделен умеренный туляремийный бактериофаг из органов морской свинки, инфицированной живой культурой туляремийного вакцинного штамма № 15 линии НИИЭГ. Установлено, что негативные колонии бактериофага до 2,0 мм в диаметре с зоной неполного лизиса по периферии. По результатам электронной микроскопии бактериофаг представляет собой корпускулы нитевидной формы. Бактериофаг лизирует бактерии возбудителей туляремии трех подвидов, а также основных видов возбудителей болезни легионеров. Простота использования выделенного бактериофага позволяет рекомендовать новый туляремийный бактериофаг ГАЛ для применения на практике.
\end{abstract}

Ключевые слова: туляремия, умеренный туляремийный бактериофаг, свойства, диагностика.

В настоящее время заболевания туляремией регистрируются в виде спорадических случаев или эпидемических вспышек разной интенсивности. Число случаев туляремии в последнее десятилетие колеблется от 100 до 400 в год, при этом около $75 \%$ заболеваний зарегистрировано в трех регионах Российской Федерации: Северном, Центральном и Западно-Сибирском. Характерной особенностью заболеваемости последних лет является существенное увеличение доли больных среди жителей городов (до $75 \%$ от общего числа случаев). Периодически, примерно с десятилетним интервалом, возникают подъемы эпизоотической активности, которые зачастую сопровождаются эпидемическими осложнениями [11].

Современное состояние природных очагов туляремии в Российской Федерации вызывает определенную настороженность у эпидемиологов. Так, в 2005 г. В Российской Федерации зарегистрирован 881 случай заболевания людей туляремией (уровень заболеваемости составил 0,60 на 100 тыс. населения). Этот показатель в 6,78 раза превышает уровень заболеваемости в аналогичный период предыдущего года [7]. Сроки установления окончательного диагноза у лиц с подозрением на данное заболевание были весьма длительными в связи с поздним обращением больных и значительной продолжительностью лабораторных исследований. В большинстве случаев диагноз туляремии поставлен ретроспективно на основании результатов иммунологических тестов [2].

Повышение заболеваемости людей туляремией свидетельствует об активизации природных очагов и уменьшении иммунной прослойки среди населения.

Напряженная эпидемическая обстановка, сложившаяся в последнее время в РФ по ряду инфекционных заболеваний, включая туляремию, и неблагоприятный прогноз ее развития на ближайшие годы, диктуют необходимость совершенствования средств их диагностики.

В настоящее время используются в диагностике туляремии бактериологические, иммунологические и молекулярно-генетические методы исследования. Вместе с тем следует отметить, что в схеме лабораторной диагностики большинства особо опасных заболеваний бактериальной природы используются специфичные бактериофаги, позволяющие в короткие сроки и с высокой степенью достоверности идентифицировать выделенную микробную культуру.

Отсутствие подобного препарата для диагностики туляремии существенно снижает эффективность противоэпидемических и лечебно-профилактических мероприятий.

До настоящего времени вопрос о наличии у возбудителя туляремии специфического бактериофага оставался открытым. Проведенный нами патентный поиск по фондам описаний изобретений России и ведущих зарубежных стран показал отсутствие данных о фактах об́наружения и способах выделения туляремийного бактериофага.

Мнения исследователей о наличии бактериофага у туляремийного микроба неоднозначны. Одни авторы утверждают, что у франциселл нет собственных фагов [5], а другие приводят данные об обнаружении феномена бактериофагии у туляремийного микроба [8]. Обстоятельное исследование этого феномена туляремийного микроба выполнила О.С.Емельянова $[6,10]$. По заключению автора, обнаруженный литический агент относится к умеренным фагам. Однако выделить и изучить туляремийный бактериофаг авторам не удалось.

Туляремия считается труднодиагностируемой инфекцией, несмотря на внедрение в практику лабораторных исследований ряда современных иммунологических и молекулярно-генетических методов. Эффективность диагностических мероприятий могла бы быть существенно повышена за счет использования специфического туляремийного бактериофага

Целью настоящей работы явилось выделение туляремийного бактериофага и изучение его основных морфологических и физиологических свойств. 


\section{Материалы и методы}

Бактериофаг выделен из органов морской свинки методом обогащения с «подсевом». Инфицированных живой культурой туляремийного вакцинного штамма № 15 линии НИИЭГ лабораторных животных усыпляли хлороформом через 6-14 сут после их заражения. Гомогенаты из паренхиматозных органов эвтаназированных животных заливали небольшим количеством забуференного физиологического раствора $\mathrm{NaCl}(\mathrm{pH} 7,0)$ и фильтровали через свечу Шамберлана. Полученные фильтраты вносили во флаконы с односуточной культурой Francisella tularensis штамма № 15 линии НИИЭГ, выращивали в статических условиях при температуре от +36 до $+38^{\circ} \mathrm{C}$ в течение 48 ч. Затем каждый флакон инокулировали $0,1 \mathrm{~cm}^{3}$ суспензии агаровой культуры F. tularensis, выращенной на FT-агаре, содержащей $1 \cdot 10^{9} \mathrm{KOE}^{-3}$ по стандартному образцу мутности ГИСК им. Л.А.Тарасевича. В качестве жидкой питательной среды использовали бульон на основе ферментативного гидролизата мяса, разведенного дистиллированной водой до содержания аминного азота 145-155 мг\% дм ${ }^{-3}$ с добавлением на 1,0 дм $^{3} 0,5$ г $\mathrm{NaCl} ; 1,0$ г $\mathrm{Na}_{2} \mathrm{HPO}_{4} \cdot 12 \mathrm{H}_{2} \mathrm{O} ; 0,2$ г $\mathrm{KCl} ; 0,25$ г дрожжевого экстракта; 0,5 г L-цистеина.

После 3-15 сут инкубирования при температуре $36-38^{\circ} \mathrm{C}$ в статических условиях культуры фильтровали через нитроцеллюлезный фильтр с диаметром пор 0,2 мкм. Фильтраты проверяли на присутствие в них туляремийного бактериофага по методу агаровых слоев Грациа $[4,9]$ с предварительным инкубированием смеси (фаг и культура) в термостате при температуре $36-38{ }^{\circ} \mathrm{C}$ в течение 20 мин. Спектр литического действия, адсорбционную способность, продолжительность латентного периода внутриклеточного развития выделенного фага, средний урожай фаговых частиц на одну инфицированную клетку определяли методом М.Адамса [1]. Тепловую инактивацию проводили путем нагревания суспензии бактериофага в $0,1 \mathrm{M}$ фосфатном буфере в термостате на водяной бане. Для электронно-микроскопических исследований препараты готовили путем адсорбции бактериофагов на поверхности сеток, покрытых формваровой подложкой, укрепленной углеродом и деионизированной непосредственно перед употреблением. Время адсорбции составляло 10 мин. Препараты контрастировали $1,0 \%$ водным раствором уранилацетата в течение $30 \mathrm{c}$, после чего промывали на каплях воды и высушивали. Препараты просматривали на микроскопе Jeol $100 \mathrm{~S}$ при увеличении $\times 30000$. Экспериментальные исследования выполняли с соблюдением Правил проведения работ с использованием экспериментальных животных. Для получения антифаговой сыворотки были использованы кролики массой от 3 до 5 кг. Иммунизацию проводили по методу М.Адамса [1].Статистическую обработку данных проводили общепринятыми методами с использованием критерия Стьюдента $(\mathrm{p}<0,05)$ [3].

\section{Результаты и обсуждение}

При посеве фильтрата методом агаровых слоев туляремийный бактериофаг формировал мутные, с нечетким неровным краем округлые негативные колонии, а также колонии с прозрачным центром и зоной неполного лизиса по периферии, диаметр которых не превышал 2,0 мм. Мутные негативные колонии (НК) имели следы роста индикаторной культуры (рис. 1). Выделение «чистой〉 линии бактериофага проводили путем многократных пересевов из изолированных НК без признаков вторичного роста бактерий.

Такой методический подход позволил получить «чистую» линию фага, который формировал негативные колонии на двухслойном FT-агаре, приготовленном по методу Грациа, с индикаторной культурой F. tularensis штамма № 501. Туляремийный бактериофаг через 48 ч инкуб́ирования при температуре $36-38{ }^{\circ} \mathrm{C}$ образовывал прозрачные колонии округлой формы с относительно ровным краем до 2,0 мм в диаметре, но при микроскопии на дне НК выявлялся слабовыраженный рост индикаторной культуры. Нанесение фаговой суспензии на газон индикаторной культуры по методу Отто [9] вызвало через 48 ч термостатирования при температуре $36-38^{\circ} \mathrm{C}$ образование зоны специфического лизиса в виде «стерильного» пятна или четко контурируемого мутного пятна, или группы мелких негативных пятен.

Адсорбция фага индикаторными бактериями в жидкой среде составляла не менее $90 \%$. Продолжительность латентного периода равна 4 ч. Средний выход фага из одной инфицированной клетки составляет $10 \pm 3$ корпускул. При иммунизации кроликов суспензий бактериофага с адьювантом Фрейнда образовывались специфические антитела. Полученная антифаговая сыворотка в разведении 1:100 инактивировала не менее $90 \%$ бактериофага.

Фаг термолабилен. Инактивация начинается при температуре $50{ }^{\circ} \mathrm{C}$, а полное разрушение происходит после инкубации при температуре $55^{\circ} \mathrm{C}$ в течение 30 мин.

При посевной дозе $1 \cdot 10^{6} \mathrm{KOЕ} \mathrm{в} 1,0 \mathrm{~cm}^{-3}$ односуточной агаровой культуры и множественности инфекции 0,010-0,001 в течение 24-36 ч инкубирования при температуре $36{ }^{\circ} \mathrm{C}$ накапливалось

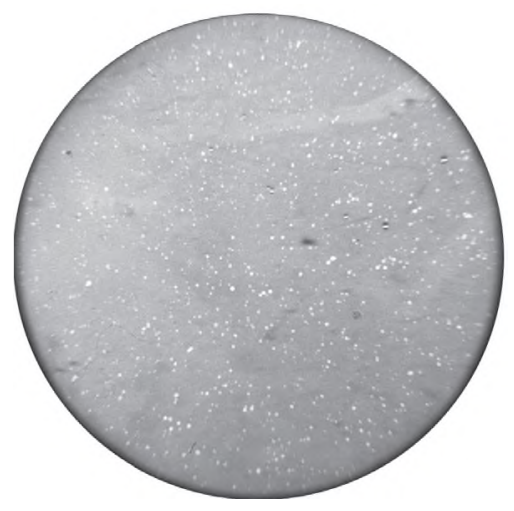

Рис. 1. Негативные колонии туляремийного бактериофага ГАЛ 
до $1 \cdot 10^{4} \mathrm{BOE} \cdot \mathrm{cm}^{-3}$.

Изучение ультраструктуры туляремийного фага показало, что он относится к первой морфологической группе вирусов бактерий по классификации А.С.Тихоненко [13]. По результатам электронной микроскопии бактериофаг представляет собой корпускулы нитевидной формы толщиной до 20 нм и длиной до 400 нм (рис. 2). Тип нуклеиновой кислоты - ДНК, молекулярная масса 20 кв.

Бактериофаг лизирует бактерии возбудителей туляремии трех подвидов (средне-азиатского, неарктического и голарктического), а также основных видов возбудителей болезни легионеров (Legionella pneumophila, Legionella micdadei, Legionella bozemanii, Legionella dumoffii). Бактериофаг не оказывает литического действия на Yersinia pestis, Vibrio cholera eltor, Bacillus anthracis, Brucella abortus, Yersinia pseudotuberculosis, Escherichia coli, Salmonella choleraesuis, Streptococcus faecium, Streptococcus equi, Streptococcus pneumoniae, Staphylococcus saprophyticus и Staphylococcus aureus, Micrococcus luteus, Bacillus subtilis, Proteus vulgaris и Proteus mirabilis, Shigella sonnei и Shigella flexneri, Serratia marcescens, Pseudomonas aeroginosa, Pasteurella multocida, Burkcholderia mallei, Burkcholderia pseudomallei, Listeria monocytogenes.

Важно отметить, что выделенный фаг не способен лизировать бактерии Francisella novicida - близкородственного по отношению к F. tularensis микроба.

Лизирующее действие туляремийного бактериофага в отношении легионелл определяли с использованием питательной среды на основе $B C Y E$ (a)-агара, так как последние, в отличие от туляремийного микроба, не растут на FT-агаре. Эти отличительные ростовые характеристики уже на этапе индикации позволяют дифференцировать возбудительей туляремии и легионеллеза.

В результате проведенных исследований впервые выделен штамм туляремийного бактериофага, обладающий специфической литической активностью в отношении $F$. tularensis и основных видов болезни легионеров. Бактериофаг депонирован в коллекции фагов ФГУ «48 ЦНИИ Минобороны России» под обозначением ГАЛ. Интерпретируя обнаружен-

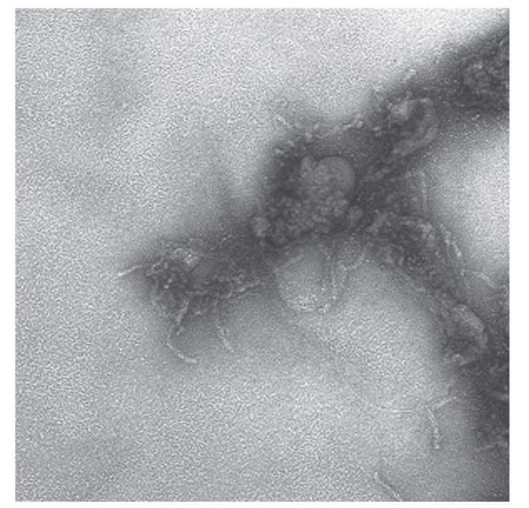

Рис. 2. Корпускулы туляремийного бактериофага ГАЛ. Контрастирование уранилацетатом. $× 3000$ ную у туляремийного бактериофага способность лизировать бактерии основных видов возбудителя легионеллеза, необходимо отметить, что противотуляремийная сыворотка в некоторых случаях также дает «перекрест》 в серологических реакциях с антигеном возбудителя болезни легионеров [12]. По-видимому, на поверхности клеточных оболочек всех названных микроорганизмов имеются близкие по антигенной специфичности рецепторы, обеспечивающие начальные этапы литического процесса при использовании фага ГАЛ в максимальных концентрациях. Природа обнаруженного явления, возможно, обусловлена тесным филогенетическим родством данных микроорганизмов.

Необходимо отметить, что имевшие место ранее неудачные попытки выделения туляремийного бактериофага обусловлены, на наш взгляд, его чувствительностью к L-цистеину. При этом возбудитель туляремии отличается высокой требовательностью к составу искусственных питательных сред, и обязательным и незаменимым компонентом жидких и плотных питательных сред для выращивания туляремийных бактерий является L-цистеин. Известно, что $\mathrm{L}$-цистеин оказывает прямое фагоцидное действие на свободные бактериофаги [4]. Для уменьшения прямого противофагового действия L-цистеина нами был использован модифицированный двухслойный метод Грациа, включающий предварительную инкубацию смеси (фаг и культура) в термостате, в процессе которой, по-видимому, происходит необратимая адсорбция фаговых частиц на поверхности туляремийных бактерий. B таких условиях L-цистеин, обладающий фагоцидными свойствами, в меньшей степени воздействует на бактериофаг, связанный с бактериальной клеткой, и не подавляет репродукцию фага внутри туляремийных бактерий.

В настоящее время, несмотря на использование новейших диагностических методов, основное значение при лабораторной диагностике туляремии придается бактериологическим исследованиям, поскольку только выделение культуры $F$. tularensis является бесспорным доказательством заболевания. Все остальные методы, будь то иммунологические, молекулярно-генетические, пригодны лишь для постановки предварительного или ретроспективного диагноза.

Простота использования выделенного бактериофага позволяет рекомендовать его для применения на практике. Использование бактериофага ГАЛ в комплексе с другими методами лабораторной диагностики позволит повысить информативность анализа и, следовательно, улучшить качество лабораторной диагностики туляремии.

Таким образом, в ходе многолетнего поиска впервые удалось выделить умеренный туляремийный бактериофаг ГАЛ и разработать способ его получения. Диагностический бактериофаг ГАЛ может быть использован в научных и практических лабораториях, занимающихся индикацией и идентификаци- 
ей возбудителя туляремии, выделяемого из организма больного и контаминированных объектов внешней среды, а также для изучения физиологических свойств и поверхностных структур штаммов туляремийного микроба.

\section{СПИСОК ЛИТЕРАТУРЫ}

1. Адамс М. Бактериофаги.М: 1961.

2. Антонов A.B. Клинико-эпидемиологическая характеристика туляремии в Краснодарском крае Медицинская микробиология - XXI век. Матер. Всерос. науч.-практ. конф. Саратов; 2004. C. $23-4$.

3. Аимарин И.П., Воробьев А.А. Статистические методы в микробиологических исследованиях. Л.: Медгиз; 1963

4. Гольдфарб Д.М. Бактериофагия. М.: Медгиз; 1961.

5. Домарадский И.В. Проблемы патогенности франписелл и пути их решения. Журн. микробиол., эпидемиол. и иммунобиол. $2005 ; 1: 106-11$

6. Емельянова О.С. О туляремийном бактериофаге. Пробл особо опасньгх инф. 1971; 3(19):202-6.

7. Здоровье населения и среда обитания. Информ. бюл. 2005; 12(153).

8. Копядиџкая Л.С., Кучина К.В., Нмурысина А.Г. О туляремийном бактериофаге Журн. микробиол., эпидемиол. и иммунобиол. 1959; 3:13-6.

9. Лабинская А.С. Микробиология с техникой микробиологических исследований. М:; 1978

10. Олсуфьев H.H. Таксономия, микробиология и лабораторная диагностика возбулителя туляремии М: 1975.

11. Приказ МЗ РФ № 125 от 14.04.1999 г. И.С. Болезнь легионеров. М:: Медицина; 1984.

13. Тихоненко A.C. Ультраструктура вирусов бактерий
A.A.Grigor'ev, I.V.Borisevich, I.V.Darmov, V.P.Bondarev, S.L.Kuznetsov,

A.V.Mironin, I.P.Pogorelsky, A. V.Letarov, E.E.Koulikov, A.A.Manykin

\section{Isolation of GAL Tularemia Bacteriophage and its Characteristics}

Russian Ministry of Defense 48 Research Institute, Kirov; S.N.Vinogradsky Institute of Microbiology,

D.I.Ivanovsky Research Institute of Virology, Moscow

Temperate tularemia bacteriophage was for the first time isolated from the organs of guinea-pig infected with live tularemia vaccine strain N 15 of RIEH line. Negative colonies of bacteriophage were up to $0.2 \mathrm{~mm}$ in diameter with incomplete lysis zone at the periphery. In view of the results of electronic microscopy bacteriophage represented filamentous carpuscules. Bacteriophage lyzed bacteria of three subtypes of tularemia etiological agent and bacteria of the main species of legionellosis etiological agents. The simple use of bacteriophage allows to recommend new tularemia bacteriophage GAL for practical application.

Key words: tularemia, temperate tularemia bacteriophage, characteristics, diagnostics.

Об авторах:

Григорьев A.A. (нач. лаб.), Борисевич И.В. (нач. института), Дармов И.B. (зам. нач. института), Бондарев $B . \Pi$. (нач. филиала), Кузнецое С.Л. (нач. отд.), Миронин А.В. (нач. отд.), Погорельский И.П. (вед.н.с.). 48 НИИ Минобороны России. Киров.

Летаров А.В. (зав. лаб.), Куликов Е.Е. (с.н.с.). Институт микробиологии им. С.Н.Виноградского РАН. 117312, Москва, Проспект 60-летия Октября, д. 7, корп. 2. Тел. : (499) 135-21-39. E-mail: inmi@inmi.host.ru Маныкин А.A. (н.с.). НИИ вирусологии им. Д.И.Ивановского PAMH. 123098, Москва, ул. Гамалеи, д. 16. Тел.: (495) 190-28-74. E-mail: info@virology.ru 